\title{
Bird diversity along a gradient of fragmented habitats of the Cerrado
}

\author{
SHAYANA DE JESUS ${ }^{1}$, WAGNER A. PEDRO ${ }^{2}$ and ARTHUR A. BISPO ${ }^{3}$ \\ ${ }^{1}$ Programa de Pós-Graduação em Biologia Animal, Universidade Estadual Paulista "Júlio de Mesquita \\ Filho”, Rua Cristóvão Colombo, 2265, 15054-000 São José do Rio Preto, SP, Brazil \\ ${ }^{2}$ Universidade Estadual Paulista "Júlio de Mesquita Filho", Rua Clóvis Pestana, 793, 16050-680 Araçatuba, SP, Brazil \\ ${ }^{3}$ Universidade Federal de Goiás, Instituto Neotropical: Pesquisa e Conservação, TheMetaLand: Laboratório de Ecologia \\ Teórica, Metacomunidades e Ecologia de Paisagem, Caixa Postal 24265, 74690-970 Goiânia, GO, Brazil
}

Manuscript received on June 23, 2016; accepted for publication on August 17, 2016

\begin{abstract}
Understanding the factors that affect biodiversity is of central interest to ecology, and essential to species conservation and ecosystems management. We sampled bird communities in 17 forest fragments in the Cerrado biome, the Central-West region of Brazil. We aimed to know the communities structure pattern and the influence of geographical distance and environmental variables on them, along a gradient of fragmented habitats at both local and landscape scales. Eight structural variables of the fragments served as an environmental distance measurement at the local scale while five metrics served as an environmental distance measurement at the landscape scale. Species presence-absence data were used to calculate the dissimilarity index. Beta diversity was calculated using three indices $\left(\beta_{\text {sim }}, \beta_{\text {nes }}\right.$ and $\left.\beta_{\text {sor }}\right)$, representing the spatial species turnover, nestedness and total beta diversity, respectively. Spatial species turnover was the predominant pattern in the structure of the communities. Variations in beta diversity were explained only by the environmental variables of the landscape with spatial configuration being more important than the composition. This fact indicates that, in Cerrado of Goiás avian communities structure, deterministic ecological processes associated to differences in species responses to landscape fragmentation are more important than stochastic processes driven by species dispersal.
\end{abstract}

Key words: beta diversity, environmental distance, forest fragments, landscape scale, turnover.

\section{INTRODUCTION}

Understanding the processes responsible for the emergence and maintenance of beta diversity is essential to biodiversity conservation and management of ecosystems. These processes play a key role in the identification and conservation planning and proposition of ecological restoration

Correspondence to: Shayana de Jesus

E-mail: shayanabio@gmail.com practices (e.g., Gutiérrez-Cánovas et al. 2013, Kattan et al. 2006, Margules and Pressey 2000, McKnight 2007, Pressey et al. 1993). In addition, as beta-diversity represents changes in both richness and identity of species, it is advantageous to detect changes that are too subtle or too complex to be noticed in species richness (Banks-Leite et al. 2012).

Variation in communities along a gradient of habitats (beta-diversity) can be assigned to two 
distinct phenomena: the spatial species turnover and the nestedness of communities. They are the outcome of species replacement and the loss or gain of species, two contrasting processes, respectively (Baselga et al. 2007, Baselga 2010). In all situations in which two or more communities are not identical, these communities will be described by any of these patterns or a combination of the two (Baselga 2010). As turnover and nestedness are patterns generated by different processes, the partitioning of beta diversity into these two components ensures a clearer understanding of the mechanisms responsible for variations in communities composition (Svenning et al. 2011). The differentiation of such components is also fundamental to the understanding of biogeographical, ecological and conservation issues (Baselga 2010).

When species distributions are structured by a nested pattern, poorer communities represent a subset of those with larger species numbers (Ulrich and Gotelli 2007, Ulrich et al. 2009). Nested communities result from a non-random process of species loss or gain (Baselga 2010). In animal communities, this pattern may be promoted by several factors such as the structure and quality of habitat, size and isolation of habitat patches and, natural and anthropogenic disturbances. These factors may act independently or interact in combinations (e.g., Bloch et al. 2007, FernándezJuricic 2002, González-Oreja et al. 2012, GutiérrezCánovas et al. 2013, Wright et al. 1998).

On the other hand, in communities structured by the spatial turnover, the species composition vary between communities due to environmental differences among sites or spatial and historical constraints (Baselga 2010, Chen et al. 2011, Qian et al. 2005). The forest fragmentation process can cause many environmental changes that affect biodiversity (Fahrig 2003, Haddad et al. 2015). In fragmented landscapes, species-specific responses to environmental changes (e.g., Uezu et al. 2005) and habitat fragmentation in different landscapes (e.g., Watson et al. 2005) may result in a pattern of species replacement along the fragmentation gradient (e.g., Banks-Leite et al. 2012).

Beta diversity can be influenced not only by geographical distance (Keil et al. 2012, Qian et al. 2005) but also by environmental dissimilarity (Jankowski et al. 2009, Veech and Crist 2007) or it can even be the result of the interaction of both factors (Baselga and Jiménez-Valverde 2007, Chen et al. 2011, Steinitz et al. 2006, Tuomisto et al. 2003). When the geographical distance is the most important factor, the species composition will fluctuate randomly through space, indicating that the structure of the community is based on limited dispersion (Legendre et al. 2005, Tuomisto and Ruokolainen 2006). When the environmental differences are the most important factors, the species composition will vary along the environmental gradient as a result of the different species-specific responses (Tuomisto and Ruokolainen 2006). Furthermore, the communities may be influenced not only by local environmental factors, but also by those at the landscape scale (e.g., Banks-Leite et al. 2012, Cleary et al. 2005, Zurita and Bellocq 2010). Therefore, it is essential to study beta diversity at different scales.

The Cerrado biome is one of the 35 regions considered as biodiversity hotspots (Mittermeier et al. 2011). It is under an increasing anthropogenic pressure due to the expansion of agricultural activities (Ferreira et al. 2013, Sano et al. 2010, Silva et al. 2013). In this context, understanding the factors responsible for structuring animal communities in fragmented landscapes is of particular importance from a conservationist point of view. It may assist in elaborating effective measures to species and their habitats conservation and management. To our knowledge, specific studies of this nature have not been carried out in the Brazilian Cerrado in terms of its avifauna. On the other hand, distinct studies with many 
different focus have been conducted in this biome. Among them, those made by Silva (1995, 1996, 1997) can be highlighted. Silva (1995) made an overview of the Cerrado's avian diversity, noting that the vast majority of resident bird species in this biome are forest dependent. Additionally, the biotic exchange with adjacent biomes had a more important role in determining the regional bird diversity than the production of species. In the gallery forests of the Cerrado region, Silva (1996) examined the distribution of birds that have their distribution centers in Amazonia and Southern Atlantic forest. This author suggested that both historical and ecological factors might explain the differences in the distribution of Amazonian and Atlantic elements within this biome. Subsequently, Silva (1997) examined the distribution of bird species endemic to this region and discussed some conservation aspects.

In order to contribute to the understanding of factors responsible for bird communities structure in the Cerrado, in the present study, we intend to identify the factors responsible for variation in bird communities composition (beta diversity) of forest fragments in the Cerrado of Goiás. Thus, we aim to elucidate the following issues: (1) if bird communities in these fragments are structured by nestedness or spatial species turnover patterns; and (2) if the variation in species composition between the fragments are influenced by the geographical distance, the structural variables of the fragments (local scale) or the environmental variables of the surrounding landscapes (landscape scale). As the process of forest fragmentation may alter the environmental conditions and species have specific ecological requirements, we expect them to respond differently to such changes. Furthermore, we expect to find dissimilarities in species composition between the fragments promoted by the species replacement mechanism as a result of environmental fluctuation mainly. We predict that environmental characteristics of the landscape are more important than local characteristics in structuring these communities due to the fact that the fragments are inside of a natural mosaic composed of different vegetation types including forest, savanna and grassland. Additionally, the fragments are in landscapes with different levels of fragmentation.

\section{MATERIALS AND METHODS}

\section{STUDY AREA}

The field work was conducted in 17 forest fragments located throughout the State of Goiás, in the Central-West region of Brazil (Figure 1, Table I). The fragments ranged from 92 to 537 ha (Table I). They are located in landscapes with different levels of forest coverage, fragmentation and connectivity. Two fragments are located in protected areas, one at "The National Forest of Silvânia" (C11) and the other at "Emas National Park" (S15). The others are inside of private properties.

The study area is covered by the Cerrado, which is the second largest Brazilian biome (IBGE 2004). This biome is a natural mosaic of 11 general physiognomies comprised of four forest, four savannic and three grassland formations (Ribeiro and Walter 2008). The climate of the region is tropical moist/dry, according to the Strahler classification (Ayoade 2012), with dry winters and rainy summers (Ribeiro and Walter 2008). The rainy season extends from October to April, and the dry season from May to September (Lima and Silva 2008). The annual mean temperature is $23.4^{\circ}$ $\mathrm{C}$, and the annual mean precipitation is $1500 \mathrm{~mm}$ (Cardoso et al. 2014, Silva et al. 2008).

\section{SAMPLING OF FRAGMENT STRUCTURAL VARIABLES}

Three plots of $10 \times 10 \mathrm{~m}$ were placed in each fragment along trails within the forest. They were located at the beginning, the middle and the end of the mist nets transect. The following structural 


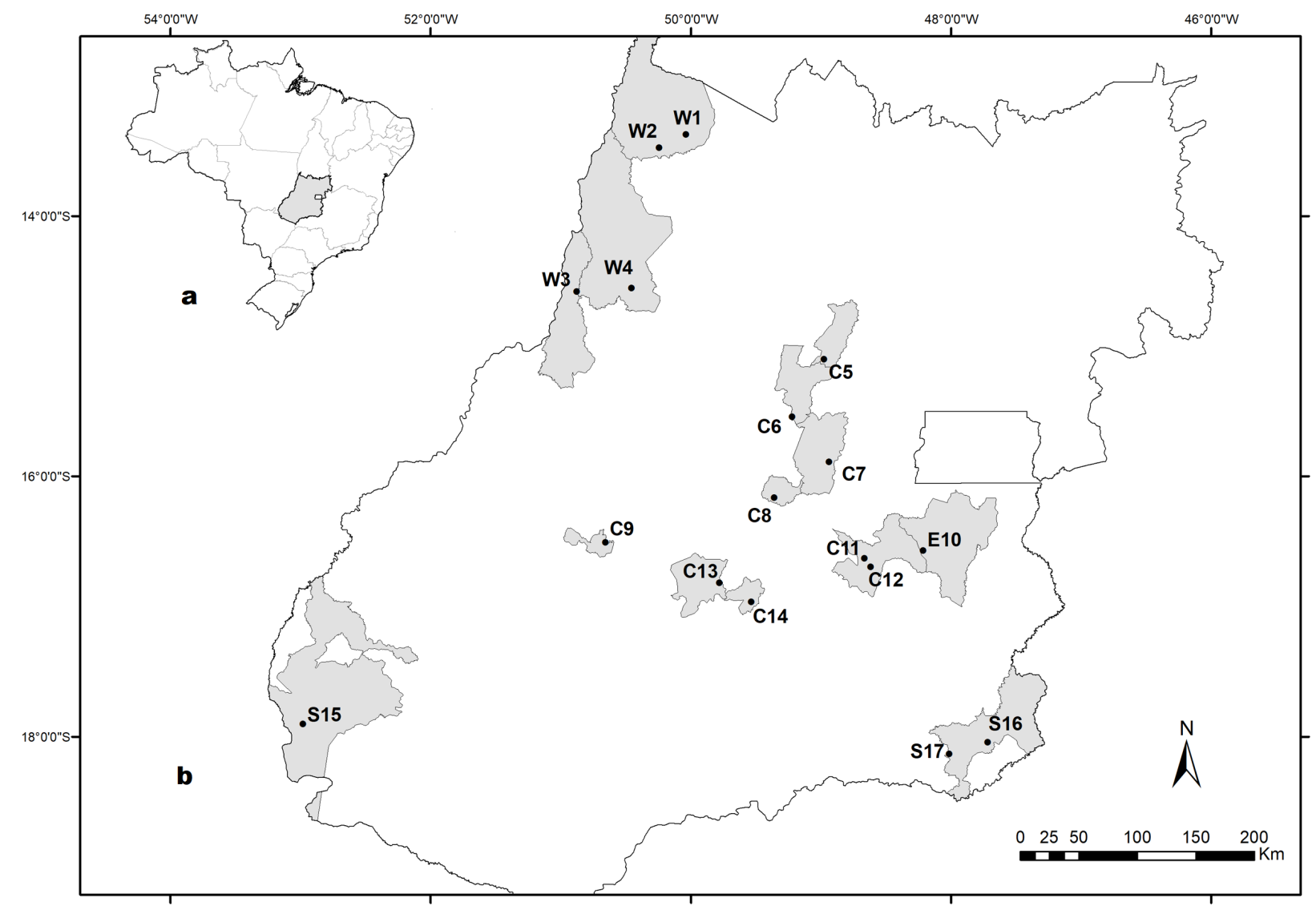

Figure 1 - (a) Map of Brazil with Goiás State highlighted. (b) Location of the seventeen forest fragments sampled in the State of Goiás. The gray areas are the municipalities where the fragments are located. The forest fragments are signaled with black dots. The fragments are numbered from the west to the south region and identified with the initial letters of the respective regions of the State (W: west; E: east; C: central; S: south).

habitat variables were collected in each plot: height of leaf litter (HLL), percentage of understory coverage (PUC), percentage of canopy coverage (PCC), number of trees higher than $1.50 \mathrm{~m}$ and diameter at breast height greater than $5 \mathrm{~cm}$ (NTT), average diameter at breast height (DBH), number of decaying trees (NDT), number of fallen logs (NFL), and number of lianas (LIA). Leaf litter height was measured with a graduated ruler at the four plot corners and at the center of each plot, totalizing five samples per plot. The understory coverage was estimated using a $2-\mathrm{m}$ rod marked at $20-\mathrm{cm}$ intervals, totalizing 10 intervals. Measurements were taken at the four corners of the plot. The rod was placed at one corner at a time and an observer, at the diagonal opposite side, estimated the number of sessions covered by vegetation. Canopy coverage readings were taken using a densiometer at the central point and at the four corners of each parcel. The reading procedures consisted of virtually dividing each quadrant into four parts. Then, we systematically counted the amount of quadrant quarters that represented the canopy. All living trees higher than $1.50 \mathrm{~m}$ and with diameter at breast height greater than $5 \mathrm{~cm}$, decaying trees with diameter at breast height greater than $5 \mathrm{~cm}$, fallen $\operatorname{logs}$ and lianas in the parcel were directly quantified. These eight structural variables served as a measure of environmental distance at the local scale. 
TABLE I

Sampled forest fragments and respective municipalities, geographical coordinates, area (hectares) and sampling period (month/year). The fragments are identified with the initial letters of the regions of the state (W: west; E: east; C: central; S: south).

\begin{tabular}{cccccc}
\hline Fragments & Municipalities & Latitude & Longitude & Area & Sampling period \\
\hline W1 & São Miguel do Araguaia & -13.3741 & -50.0372 & 92.31 & $01 / 2014 ; 05 / 2014$ \\
W2 & São Miguel do Araguaia & -13.4769 & -50.2434 & 352.99 & $11 / 2013 ; 05 / 2014$ \\
W3 & Aruanã & -14.5830 & -50.8784 & 102.05 & $01 / 2014 ; 08 / 2014$ \\
W4 & Nova Crixás & -14.5562 & -50.4558 & 138.68 & $02 / 2014 ; 08 / 2014$ \\
C5 & Barro Alto & -15.1017 & -48.978 & 537.37 & $09 / 2012 ; 04 / 2014$ \\
C6 & Goianésia & -15.5454 & -49.2237 & 114.72 & $03 / 2014 ; 07 / 2014$ \\
C7 & Pirenópolis & -15.8920 & -48.9376 & 144.11 & $02 / 2014 ; 06 / 2014$ \\
C8 & Petrolina de Goiás & -16.1669 & -49.3605 & 253.83 & $02 / 2013 ; 10 / 2013$ \\
C9 & Moiporá & -16.5110 & -50.6581 & 222.53 & $10 / 2013 ; 05 / 2014$ \\
E10 & Luziânia & -16.5717 & -48.2145 & 174.39 & $11 / 2013 ; 07 / 2014$ \\
C11 & Silvânia & -16.6318 & -48.6669 & 142.92 & $12 / 2012 ; 09 / 2013$ \\
C12 & Silvânia & -16.6987 & -48.6176 & 109.68 & $09 / 2012 ; 02 / 2014$ \\
C13 & Palmeiras de Goiás & -16.8221 & -49.7828 & 107.12 & $02 / 2013 ; 08 / 2013$ \\
C14 & Guapó & -16.9660 & -49.5351 & 196.48 & $11 / 2012 ; 09 / 2013$ \\
S15 & Mineiros & -17.9065 & -52.9835 & 102.26 & $12 / 2013 ; 08 / 2014$ \\
S16 & Catalão & -18.0461 & -47.7186 & 196.85 & $03 / 2013 ; 08 / 2013$ \\
S17 & Catalão & -18.1352 & -48.0136 & 252.10 & $08 / 2013 ; 04 / 2014$ \\
\hline
\end{tabular}

\section{LANDSCAPE ANALYSIS}

After supervised classification of Landsat 8 satellite images (30-m resolution; bands 5, 4 and 3 ) and mapping of coverage classes (Forest, Cerrado, anthropogenic environment and water), we calculated landscape metrics, considering two coverage classes: forest and non-forest. The metrics were calculated using Fragstats v 4.2 (McGarigal and Marks 1995) for a $5 \mathrm{~km}$ radium from each forest fragment center. Subsequently, five metrics were selected and used together as a measure of environmental distance at the landscape scale: CA (forested area), TCA (total forest fragment core area), NP (number of forest fragments), SHAPE (mean forest fragment shape), and CLUMPY (aggregation of forest fragments). CA and TCA are composition metrics. The others represent landscape configuration metrics.

\section{BIRD COMMUNITIES SAMPLING}

Sampling in the fragments took place between September 2012 and August 2014 (Table I). Each fragment was sampled in two different seasons: dry and rainy. Sampling effort was comprised of a 15hour period in each fragment per season, totalizing 510 hours. The surveys were conducted during three consecutive days and always started at sunrise and finished five hours later. In each fragment, 20 mistnets were placed along trails within the forest and checked every 30 minutes. The captured birds were carefully removed from the nets, being identified afterward. Then, the individuals were released at the same trapping spot. A quali-quantitative sampling was also performed using the point count method (Vielliard et al. 2010). Six point-counts sites were placed, with a minimum distance of $200 \mathrm{~m}$ between each other, in each fragment. Observation sessions 
were conducted for 20 minutes at each point-count site. Species presence-absence data, obtained through two different methodologies (mist-nets and point-count), were used to calculate species dissimilarity.

\section{DATA ANALYSIS}

\section{Beta diversity}

To calculate beta diversity, we partitioned it into the nestedness and turnover components. This procedure is essential to analyze and understand the processes that are influencing beta diversity (Baselga 2010). In accordance with the methods proposed by Baselga (2010), three beta-diversity indexes were calculated: the Simpson dissimilarity index $\left(\beta_{\text {sim }}\right)$, the nestedeness index $\left(\beta_{\text {nes }}\right)$ and the Sorensen dissimilarity index $\left(\beta_{\text {sor }}\right)$. They represent the beta-diversity pattern that results from the replacement of species, beta diversity related to nestedness and total beta diversity, respectively. The indexes were calculated using the following formulas:

$$
\begin{aligned}
& \beta \operatorname{sim}=\frac{\min (b, c)}{a+\min (b, c)} \\
& \beta \text { sor }=\frac{b+c}{2 a+b+c}
\end{aligned}
$$

$$
\beta \text { nes }=1+\frac{\max (b, c)-\min (b, c)}{2 a+\min (b, c)+\max (b, c)} x \frac{a}{a+\min (b, c)}
$$

In the formulas above, $a$ represents the number of shared species by two sites, while $b$ and $c$ represent the number of species unique to each site (Baselga 2010). The indexes vary between 0 (no dissimilarity) and 1 (maximum dissimilarity, i.e. beta diversity is high).

All analysis were performed in the R software (R Development Core Team 2013) using the vegan package, based on species presence-absence data. The calculation was conducted in pairs in order to evaluate the dissimilarity between all pairs of the 17 landscapes. Afterwards, the mean beta diversity was calculated for each landscape and among the entire landscape set.

\section{Variation in beta diversity: Influence of geographical distance $x$ environmental distance}

The Mantel test evaluates the correlation between two dissimilarity matrices. Therefore, we used it to test whether the variation in beta diversity between the fragments was influenced by the geographical or environmental distances between them. The three beta-diversity indices (the Simpson index, the nestedness index, the Sorensen index) were used to calculate species dissimilarity. Geographical coordinates of the fragments were used to calculate the geographical distance. Eight structural variables of the fragments (HLL, UCP, CCP, NTT, DBH, NDT, NFL and LIA) were used to calculate the environmental distance at the local scale. Five landscape metrics (CA, NP, SHAPE, CLUMPY, and TCA) were used to calculate the environmental distance at the landscape scale, considering a $5-\mathrm{km}$ radius. We tested the influence of geographical and environmental distances on beta diversity at both local and landscape scales. The calculations were conducted in the R software (R Development Core Team 2013) using the vegan package.

\section{RESULTS}

Spatial species turnover explained most part of variation in beta diversity $\left(\beta_{\text {sim }}=0.4641,88.32 \%\right.$ of explanation) among the communities while nestedness poorly explained such variation $\left(\beta_{\text {nes }}=\right.$ $0.0614,11.68 \%$ of explanation).

Total beta diversity, species replacement and nestedness, at the local scale, were not influenced by either the geographical or the environmental distances between fragments (Table II). However, 
the environmental distance between the fragments, represented by five metrics (CA, NP, SHAPE, CLUMPY and TCA), influenced species replacement $\left(\beta_{\text {sim }}\right)$ at the local scale (Table II).

There was a relationship between the species turnover and environmental distance of the surrounding landscape. Therefore, each metric was analyzed separately in order to evaluate their influence on species diversity. Our analysis revealed that only two variables, NP (number of forest fragments) and CLUMPY (aggregation of forest fragments), had significant effects on beta diversity. These variables positively influenced not only the total beta diversity but also the species turnover (Table III).

\section{DISCUSSION}

Spatial species turnover was the predominant pattern in the structure of communities. The explanation for the replacement pattern leans on the Niche Theory. This theory posits that the distribution of each species is limited by a combination of abiotic and biotic variables that determine their multidimensional niche (Brown 1984, Hutchinson 1957). As responses to environmental factors occur in accordance with adaptations and limitations of each species (Wiens 1989), there may be changes in species composition along environmental gradients (Tuomisto and Ruokolainen 2006).

Only the variation of environmental features of the landscape had influence on the studied communities while environmental variation, at the local scale, did not influence them. The unique effects of landscape variables on bird communities are consistent with the results obtained by Seoane et al. (2004). They found that, at the landscape scale, the vegetation variables of the surrounding matrix were better predictors of bird distribution than the vegetation coverage at the local scale. However, in some cases, the bird communities may be primarily associated to local features and secondarily to features measured at a larger spatial scale (e.g., MacFaden and Capen 2002). They might also be affected by both, local and landscape variables (e.g., Cleary et al. 2005, Ikin et al. 2014, Leyequién et al. 2010). Additionally, in other situations, the environmental variables are not important to bird communities structure. For instance, Baselga et al. (2015) examined the beta diversity of bird communities in agricultural landscapes of France.

TABLE II

Partial Mantel test values ( $r=$ the correlation coefficient; $p=$ level of significance) considering geographical and environmental distances at the local scale, and geographical and environmental distances at the landscape scale of the 17 forest fragments.

\begin{tabular}{cccc}
\hline & Distance & $\mathbf{r}$ & $\mathbf{p}$ \\
\hline \multirow{2}{*}{ Total $\beta$ diversity } & geographical & -0.03279 & 0.58094 \\
& environmental - local scale & -0.08184 & 0.70293 \\
\hline \multirow{2}{*}{ Turnover } & geographical & 0.05332 & 0.38706 \\
& environmental - local scale & -0.03527 & 0.58804 \\
\hline \multirow{2}{*}{ Nestedness } & geographical & 0.1458 & 0.84402 \\
& environmental - local scale & -0.06188 & 0.63984 \\
\hline \multirow{2}{*}{ Total $\beta$ diversity } & geographical & -0.004636 & 0.47215 \\
& environmental - landscape scale & 0.08341 & 0.053195 \\
\hline \multirow{2}{*}{ Turnover } & geographical & 0.08341 & 0.28237 \\
Nestedness & environmental - landscape scale & 0.2436 & $\mathbf{0 . 0 1 8 3 9 8}$ \\
\hline
\end{tabular}


TABLE III

Partial Mantel test values $(r=$ the correlation coefficient; $p=$ level of significance) considering the geographical and environmental distances of the surrounding landscapes of the 17 forest fragments.

\begin{tabular}{|c|c|c|c|}
\hline & Distance & $\mathbf{r}$ & $\mathbf{p}$ \\
\hline \multirow[t]{2}{*}{ Total $\beta$ diversity } & geographical & -0.02987 & 0.56734 \\
\hline & environmental - CA & -0.0686 & 0.67733 \\
\hline \multirow[t]{2}{*}{ Turnover } & geographical & 0.05119 & 0.38556 \\
\hline & environmental - CA & -0.06692 & 0.68523 \\
\hline \multirow[t]{2}{*}{ Nestedness } & geographical & -0.1374 & 0.78972 \\
\hline & environmental - CA & 0.01592 & 0.38886 \\
\hline \multirow[t]{2}{*}{ Total $\beta$ diversity $\beta$} & geographical & -0.04898 & 0.62664 \\
\hline & environmental - NP & 0.2047 & 0.025297 \\
\hline \multirow[t]{2}{*}{ Turnover } & geographical & 0.03245 & 0.41546 \\
\hline & environmental - NP & 0.2116 & 0.017998 \\
\hline \multirow[t]{2}{*}{ Nestedness } & geographical & -0.1306 & 0.74963 \\
\hline & environmental - NP & -0.0691 & 0.74933 \\
\hline \multirow[t]{2}{*}{ Total $\beta$ diversity } & geographical & -0.02661 & 0.54665 \\
\hline & environmental - SHAPE & -0.026 & 0.56664 \\
\hline \multirow[t]{2}{*}{ Turnover } & geographical & 0.06001 & 0.36056 \\
\hline & environmental - SHAPE & 0.02042 & 0.42236 \\
\hline \multirow[t]{2}{*}{ Nestedness } & geographical & -0.1488 & 0.85751 \\
\hline & environmental - SHAPE & -0.07705 & 0.69613 \\
\hline \multirow[t]{2}{*}{ Total $\beta$ diversity } & geographical & -0.02949 & 0.58514 \\
\hline & environmental - CLUMPY & 0.3328 & 0.0033997 \\
\hline \multirow[t]{2}{*}{ Turnover } & geographical & 0.05696 & 0.40496 \\
\hline & environmental - CLUMPY & 0.3865 & 0.00059994 \\
\hline \multirow[t]{2}{*}{ Nestedness } & geographical & -0.1395 & 0.78862 \\
\hline & environmental - CLUMPY & -0.1895 & 0.9814 \\
\hline \multirow[t]{2}{*}{ Total $\beta$ diversity } & geographical & -0.00719 & 0.49495 \\
\hline & environmental - TCA & 0.1163 & 0.20728 \\
\hline \multirow[t]{2}{*}{ Turnover } & geographical & 0.07551 & 0.31457 \\
\hline & environmental - TCA & 0.1296 & 0.15468 \\
\hline \multirow[t]{2}{*}{ Nestedness } & geographical & -0.1459 & 0.84452 \\
\hline & environmental - TCA & -0.05624 & 0.60844 \\
\hline
\end{tabular}

They found that the change in land cover had little impact on the communities. Therefore, the authors suggested that changes in species composition were caused by stochastic processes in which species appeared and disappeared randomly from the sampled localities.

In the present study, the surveyed fragments are located in landscapes with different levels of forest coverage, fragmentation and connectivity. Some fragments are in more fragmented landscapes (e.g., C6, S16, C9 and C7) while others are located in landscapes with more connectivity (e.g., W3, S15, W4 and W2). Environmental differences of different sites can cause geographic variation in the species pool (Wright et al. 1998), as observed in this study. We found that variables that represent the landscapes configuration were more important than those variables that represent their composition. This suggests that, while some species may be disappearing from fragments 
located in very fragmented landscapes, others may be benefiting from them. Thus, the ultimate result is not species loss (which would lead to a nested pattern of communities). Actually, there is a species replacement pattern between fragments along the fragmentation gradient studied herein.

As the sampled sites are located in a fragmented region, we could expect nested bird communities in the fragments. Even though habitat fragmentation is not a direct cause of nestedness, it can contribute to the formation of communities, as fragmented landscapes have patches that differ in size and isolation (Ulrich et al. 2009). In these landscapes, habitat specialists species that are less abundant may be able to persist in larger and/or less isolated fragments. Contrastingly, these species may be extinct in smaller fragments (Ulrich et al. 2009). Such species loss can make communities in fragmented areas to become subsets of those existing communities in continuous landscapes. However, it is worth to note that many commonly used metrics can detect nestedness even in nonnested communities (Almeida-Neto et al. 2008). Thus, many previous studies may have erroneously suggested that communities in fragmented landscapes are nested subsets of those existing in intact landscapes (Banks-Leite et al. 2012).

The observed turnover as a communitystructuring pattern, the unique influence of environmental features of the landscape and the major importance of landscape configuration compared to its composition, can be explained by peculiarities of the fragmentation pattern in the Cerrado. The Cerrado is a natural vegetational mosaic primarily composed of a typical savannic coverage (Eiten 1994), interspersed with other forest and grassland physiognomies (Ribeiro and Walter 2008). Anthropogenic fragmentation in the Cerrado, which is naturally fragmented, is altering its landscape configuration. Consequently, it is also modifying the effects that the interaction among the landscape environments have on bird communities. Changes in properties of the habitat matrix can influence not only resources availability for different bird species but also the connectivity between forest fragments (Watson et al. 2005). When fragmentation creates open environments, the contrast between the surrounding matrix and the forest fragment increases, and the edge effects can be more drastic (Colli et al. 2003). Such situation may favor the establishment of edge or open-area species while the forest-interior species may be more prone to become locally extinct (Lovejoy et al. 1986, Wiens 1989). The species turnover between the fragments studied herein is the result of different species responses to changes in the landscape configuration caused by fragmentation.

Therefore, as landscape configuration is more important than habitat loss for Cerrado forest birds, it is expected that variables describing the changes in landscape configuration would be more important, as we found in our study. We believe that these results are particular to the Cerrado biome or other environments that are a natural mosaic of habitats. In the Atlantic forest, which was originally a forested landscape that covered a wide latitudinal range along the brazilian coast (Silva and Casteleti 2005), bird communities can be primarily affected by habitat loss, and secondarily by fragmentation (Zurita and Bellocq 2010). Banks-Leite et al. (2012) investigated the effect of habitat loss on bird communities in landscapes with different levels of forest coverage in the Atlantic forest in southeastern Brazil. They found that some species require a high percentage of forest coverage to persist while others can benefit from habitat loss. Such circumstances lead to a replacement in species composition. Therefore, these authors suggested that habitat loss affected each species individually in the studied communities.

Birds, in general, are a taxonomic group with great mobility. The effects of geographical distance on the beta diversity may vary due to organisms with different dispersal abilities. Bird communities 
of the Cerrado can be considered quite vagile. They frequently move between different physiognomies of the landscape in order to explore resources that are seasonally available (e.g., Cavalcanti 1992, Piratelli and Blake 2006, Tubelis and Cavalcanti 2001). In the present study, canopy species were predominant ( $\mathrm{n}=118 ; 43.38 \%$ of the total species richness). They are characterized by their greater mobility when compared to lower strata species (ground and understory). Therefore, considering the mobility of the communities studied herein, the results are in accordance with our expectations. Thus, it is understandable that environmental heterogeneity is more important than geographical distance in determining beta diversity in these communities. A recent study conducted in the Amazon, also detected the absence of geographical distance influence on the dissimilarity of bird communities. Pomara et al. (2014) sampled bird communities in upland forests situated near to the Amazon River flood plains. These authors found that the dissimilarity in species composition was explained by local floristic variation (represented by the family Melastomataceae) and forest fragmentation at the landscape scale. Therefore, even for the Amazonian birds, which tend to be more sedentary (Bierregaard 1990, Stouffer and Bierregaard 1995), environmental changes may be more important than geographical distance in the variation of the communities composition.

Species groups with lower dispersal abilities were frequently related to geographical distance when compared to groups with greater dispersion (e.g. Qian 2009, Steinitz et al. 2006, Thompson and Townsend 2006, Tuomisto et al. 2003). As an example, Nogueira et al. (2009) found that, in Cerrado regions, the lizard species turnover between different localities was highly dependent upon geographical distance. Ferro and Diniz (2007) found that beta diversity of the Arctiidae species (Insecta, Lepidoptera) was positively related to geographical distance of the sampled sites.
Only environmental distance influenced beta diversity of avian communities at the landscape scale. This indicates that deterministic ecological process, in association with different species responses to landscape connectivity and isolation, are more important than stochastic process (driven by species dispersion) in structuring bird communities in the Cerrado of Goiás. Our results also show that the fragmentation process in the Cerrado of Goiás is acting as a landscape modifier. This process is causing species replacement in the remaining forest patches along the gradient of fragmentation. In more fragmented landscapes, more sensitive species are probably disappearing and being replaced by those that are favored by environmental changes induced by fragmentation. On the other hand, less fragmented areas undergo the inverse process.

We emphasize that there is a need for developing management strategies for the entire Cerrado of Goiás order to ensure the forest avifauna conservation. In case of grassland and savanna destruction continues, even if forest areas are kept intact, the effects on forest bird communities will be observable. The forest fragments can become gradually surrounded by a predominantly anthropogenic landscape. It increases the degree of isolation of forest fragments besides affecting the movement of many bird species in these landscapes. Consequently, species that are sensitive to isolation may become locally extinct, including those species with distribution restricted to these landscapes.

\section{ACKNOWLEDGMENTS}

We thank everyone who helped us during the fieldwork, and the owners and managements who authorized the sampling inside their private areas. Paulo de Marco Jr. and Poliana Mendes for helping with the sampling design, Danielly Ferreira de Almeida for undertaking the classification of the 
Landsat images used, and Paulo Vitor dos Santos Bernardo for helping in the calculation of landscape metrics and in the analysis with $\mathrm{R}$ program. To the Instituto Chico Mendes de Conservação da Biodiversidade (ICMBio) for the exploration licenses granted (n⿳306056-1, 36056-4, 37054-1), and Centro Nacional de Pesquisa e Conservação de Aves Silvestres (CEMAVE) for licenses and metal bands ( $n^{\circ} 3554 / 1,3554 / 2$ ). Finally, we thank Coordenação de Aperfeiçoamento de Pessoal de Nível Superior (CAPES) for granting the doctorate scholarship to the main author in this article, and Fundação de Amparo à Pesquisa do Estado de Goiás (FAPEG) (Public call 05/2012; Project 039158) for the financial support to benefit the field campaigns.

\section{REFERENCES}

ALMEIDA-NETO M, GUIMARÃES P, GUIMARÃES JUNIOR PR, LOYOLA RD AND ULRICH W. 2008. A consistent metric for nestedness analysis in ecological systems: reconciling concept and measurement. Oikos 117: $1227-1239$.

AYOADE JO. 2012. Introdução à Climatologia para os Trópicos, $16^{\mathrm{a}}$ ed., Rio de Janeiro: Bertrand Brasil, 350 p.

BANKS-LEITE C, EWERS RM AND METZGER JP. 2012. Unraveling the drivers of community dissimilarity and species extinction in fragmented landscapes. Ecology 93: 2560-2569.

BASELGA A. 2010. Partitioning the turnover and nestedness components of beta diversity. Global Ecol Biogeogr 19: 134-143.

BASELGA A, BONTHOUX S AND BALENT G. 2015. Temporal Beta Diversity of Bird Assemblages in Agricultural Landscapes: Land Cover Change vs. Stochastic Processes. PLoS ONE 10: e0127913.

BASELGA A AND JIMÉNEZ-VALVERDE A. 2007. Environmental and geographical determinants of beta diversity of leaf beetles (Coleoptera: Chrysomelidae) in the Iberian Peninsula. Ecol Entomol 32: 312-318.

BASELGAA, JIMÉNEZ-VALVERDE AAND NICCOLINI G. 2007. A multiple-site similarity measure independent of richness. Biol Lett 3: 642-645.

BIERREGAARD RO. 1990. Species composition and trophic organization of the understory bird community in a Central Amazonian Terra Firme Forest. In: Gentry A (Ed), Four Neotropical Rainforests, New Haven: Yale University Press, p. 217-236
BLOCH CP, HIGGINS CL AND WILLIG MR. 2007. Effects of large-scale disturbance on metacommunity structure of terrestrial gastropods: temporal trends in nestedness. Oikos 116: 395-406

BROWN JH. 1984. On the relationship between abundance and distribution of species. Am Nat 124: 255-279.

CARDOSO MRD, MARCUZZO FFN AND BARROS JR. 2014. Classificação climática de Köppen-Geiger para o estado de Goiás e o Distrito Federal. Acta Geogr 8: 40-55.

CAVALCANTI RB. 1992. The importance of forest edges in the ecology of open country cerrado birds. In: Furley PA et al. (Eds), Nature and dynamics of forest-savanna boundaries, London: Chapman \& Hall, p. 513-518.

CHEN S, JIANG G, ZHANG J, LI Y AND QIAN H. 2011. Species turnover of amphibians and reptiles in eastern China: disentangling the relative effects of geographic distance and environmental difference. Ecol Res 26: 949956.

CLEARY DFR, GENNER MJ, BOYLE TJB, SETYAWATIS T, ANGRAETI CD AND MENKEN SBJ. 2005. Associations of bird species richness and community composition with local and landscape-scale environmental factors in Borneo. Landscape Ecol 20: 989-1001.

COLLI GR, ACCACIO GM, ANTONINI Y, CONSTANTINO R, FRANCESCHINELLI EV, LAPS RR, SCARIOT A, VIEIRA MV AND WIEDERHECKER HC. 2003. A fragmentação dos ecossistemas e a biodiversidade brasileira: uma síntese. In: Rambaldi DM and Oliveira DAS (Eds), Fragmentação de Ecossistemas: Causas, efeitos sobre a biodiversidade e recomendações de políticas públicas. Brasília: Ministério do Meio Ambiente/Secretaria de Biodiversidade e Florestas, p. 317-324.

EITEN GA. 1994. A vegetação do Cerrado. In: Pinto MN (Ed), Cerrado: Caracterização, ocupação e perspectivas. $2^{\mathrm{a}}$ ed., Brasília: UNB, SEMATEC, p. 9-65.

FAHRIG L. 2003. Effects of habitat fragmentation on biodiversity. Annu Rev Ecol Evol System 34: 487-515.

FERNÁNDEZ-JURICIC E. 2002. Can human disturbance promote nestedness? A case study with breeding birds in urban habitat fragments. Oecologia 131: 269-278.

FERREIRA ME, FERREIRA JR LG, LATRUBESSE EM AND MIZIARA F. 2013. Considerations about the land use and conversion trends in the savanna environments of Central Brazil under a geomorphological perspective. J Land Use Sci 23: 1-15.

FERRO VG AND DINIZ IR. 2007. Composição de espécies de Arctiidae (Insecta, Lepidoptera) em áreas de Cerrado. Rev Bras Zool 24: 635-646.

GONZÁLEZ-OREJA JA, DE LA FUENTE-DÍAZ-ORDAZ AA, HERNÁNDEZ-SANTÍN L, BONACHE-REGIDOR C AND BUZO-FRANCO D. 2012. Can human disturbance 
promote nestedness? Songbirds and noise in urban parks as a case study. Landscape Urban Plan 104: 9-18.

GUTIÉRREZ-CÁNOVAS C, MILLÁN A, VELASCO J, VAUGHAN IP AND ORMEROD SJ. 2013. Contrasting effects of natural and anthropogenic stressors on beta diversity in river organisms. Global Ecol Biogeogr 22: 796-805.

HADDAD NM ET AL. 2015. Habitat fragmentation and its lasting impact on Earth's ecosystems. Sci Adv 1: 1-9.

HUTCHINSON GE. 1957. Concluding remarks. Cold Spring Harb Sym 22: 415-427.

IBGE - INSTITUTO BRASILEIRO DE GEOGRAFIA E ESTATÍSTICA. 2004. Mapa de Biomas do Brasil, primeira aproximação. Rio de Janeiro: IBGE. Disponível em: <www.ibge.gov.br>. Acesso: 14 Julho 2016.

IKIN K, BARTON PS, STIRNEMANN IA, STEIN JR, MICHAEL D, CRANE M, OKADA S AND LINDENMAYER DB. 2014. Multi-Scale Associations between Vegetation Cover and Woodland Bird Communities across a Large Agricultural Region. PLoS ONE 9: e97029.

JANKOWSKI J, CIECKA AL, MEYER NY AND RABENOLD KN. 2009. Beta diversity along environmental gradients: implications of habitat specialization in tropical montane landscapes. J Anim Ecol 78: 315-327.

KATTAN GH, FRANCO P, SAAVEDRA-RODRÍGUEZ CA, VALDERRAMA C, ROJAS V, OSORIO D AND MARTÍNEZ J. 2006. Spatial components of bird diversity in the Andes of Colombia: implications for designing a regional reserve system. Conserv Biol 20: 1203-1211.

KEIL P ET AL. 2012. Patterns of beta diversity in Europe: the role of climate, land cover and distance across scales. J Biogeogr 39: 1473-1486.

LEGENDRE P, BORCARD D AND PERES-NETO PR. 2005. Analyzing beta diversity: partitioning the spatial variation of community composition data. Ecol Monogr 75: 435450 .

LEYEQUIÉN E, DE BOER WF AND TOLEDO VM. 2010. Bird community composition in a shaded coffee agro-ecological matrix in Puebla, Mexico: the effects of landscape heterogeneity at multiple spatial scales. Biotropica 42: 236-245.

LIMA JEFW AND SILVA EM. 2008. Recursos Hídricos do Bioma Cerrado: importância e situação. In: Sano SM et al. (Eds), Cerrado: Ecologia e Flora, Brasília: EMBRAPA, p. 89-106.

LOVEJOY TE ET AL. 1986. Edge effects and other effects of isolation on Amazon forest fragments. In: Soulé ME (Ed), Conservation Biology: The Science of Scarcity and Diversity. Massachusetts: Sinauer Associates, p. 257-285.
MACFADEN SW AND CAPEN DE. 2002. Avian habitat relationships at multiple scales in a New England forest. Forest Sci 48: 243-253.

MARGULES CR AND PRESSEY RL. 2000. Systematic conservation planning. Nature 405: 243-253.

MCGARIGAL K AND MARKS B. 1995. FRAGSTATS: spatial pattern analysis program for quantifying landscape structure. Portland (OR): US Department of Agriculture, Forest Service, Pacific Northwest Research Station. General Technical Report PNW-GTR-351.

MCKNIGHT MW. 2007. Broad-scale patterns and determinants of beta-diversity. A dissertation submitted to the faculty of the University of North Carolina at Chapel Hill in partial fulfillment of the requirements for the degree of Doctor of Philosophy in the Curriculum in Ecology. Chapel Hill. (Unpublished).

MITTERMEIER RA, TURNER WR, LARSEN FW, BROOKS TM AND GASCON C. 2011. Global Biodiversity Conservation: The Critical Role of Hotspots. In: Zachos FE and Habel JC (Eds), Biodiversity Hotspots: Distribution and Protection of Conservation Priority Areas, Heidelberg: Springer-Verlag Berlin, p. 3-22.

NOGUEIRA C, COLLI GR AND MARTINS M. 2009. Local richness and distribution of the lizard fauna in natural habitat mosaics of the Brazilian. Austral Ecol 34: 83-96.

PIRATELLI A AND BLAKE JG. 2006. Bird communities of the Southeastern Cerrado Region, Brazil. Ornitol Neotrop 17: 213-225.

POMARA LY, RUOKOLAINEN K AND YOUNG KR. 2014. Avian species composition across the Amazon River: the roles of dispersal limitation and environmental heterogeneity. J Biogeogr 41: 784-796.

PRESSEY RL, HUMPHRIES CJ, MARGULES CR, VANEWRIGHT RI AND WILLIAMS PH. 1993. Beyond opportunism: key principles for systematic reserve selection. Trends Ecol Evol 8: 124-128.

QIAN H. 2009. Beta diversity in relation to dispersal ability for vascular plants in North America. Glob Ecol Biogeogr 18: 327-332.

QIAN H, RICKLEFS RE AND WHITE PS. 2005. Beta diversity of angiosperms in temperate floras of eastern Asia and eastern North America. Ecol Lett 8: 15-22.

R DEVELOPMENT CORE TEAM. 2013. A Language and Environment for Statistical Computing. R Foundation for Statistical Computing, Vienna, Austria.

RIBEIRO JF AND WALTER BMT. 2008. As principais fitofisionomias do bioma Cerrado. In: Sano SM et al. (Eds), Cerrado: Ecologia e Flora, Brasília: EMBRAPA, p. 151-199.

SANO EE, ROSA R, BRITO JLS AND FERREIRA LG. 2010. Land cover mapping of the tropical savanna region in Brazil. Environ Monit Assess 166: 113-124. 
SEOANE J, BUSTAMANTE J AND DIAZ-DELGADO R. 2004. Competing roles for landscape, vegetation, topography and climate in predictive models of bird distribution. Ecol Model 171: 209-222.

SILVA EB, FERREIRA JR LG, DOS ANJOS AF AND MIZIARA F. 2013. A expansão da fronteira agrícola e a mudança de uso e cobertura da terra no centro-sul de Goiás, entre 1975 e 2010. Ateliê Geográfico 7: 116-138.

SILVA FAM, ASSAD ED AND EVANGELISTA BA. 2008. Caracterização Climática do Bioma Cerrado. In: Sano SM et al. (Eds), Cerrado: Ecologia e Flora, Brasília: EMBRAPA, p. 69-88.

SILVA JMC. 1995. Birds of the Cerrado Region, South America. Steenstrupia 21: 69-92.

SILVA JMC. 1996. The distribution of Amazonian and Atlantic forest elements in the gallery forests of the Cerrado Region. Ornitol Neotropical 7: 1-18.

SILVA JMC. 1997. Endemic bird species and conservation in the Cerrado Region, South America. Biodivers Conserv 6: 435-450.

SILVA JMC AND CASTELETI CHM. 2005. Estado da biodiversidade da Mata Atlântica brasileira. In: Galindo-Leal C and Câmara IG (Eds), Mata Atlântica: Biodiversidade, Ameaças e Perspectivas. Belo Horizonte: Fundação SOS Mata Atlântica Conservação Internacional, p. 43-59.

STEINITZ O, HELLER J, TSOAR A, ROTEM D AND KADMON R. 2006. Environment, dispersal and patterns of species similarity. J Biogeogr 33: 1044-1054.

STOUFFER PC AND BIERREGAARD RO. 1995. Use of Amazonian forest fragments by understory insectivorous birds. Ecology 76: 2429-2495.

SVENNING J, FLØJGAARD C AND BASELGA A. 2011. Climate, history and neutrality as drivers of mammal beta diversity in Europe: insights from multiscale deconstruction. J Anim Ecol 80: 393-402.

THOMPSON R AND TOWNSEND C. 2006. A truce with neutral theory: local deterministic factors, species traits and dispersal limitation together determine patterns of diversity in stream invertebrates. J Anim Ecol 75: 476-484.

TUBELIS DP AND CAVALCANTI RB. 2001. Community similarity and abundance of bird species in open habitats of a central Brazilian Cerrado. Ornitol Neotropical 12: 57 73.

TUOMISTO H AND RUOKOLAINEN K. 2006. Analyzing or explaining beta diversity? Understanding the targets of different methods of analysis. Ecology 87: 2697-2708.

TUOMISTO H, RUOKOLAINEN K AND YLI-HALLA M. 2003. Dispersal, environment, and floristic variation of western Amazonian forests. Science 299: 241-244.

UEZU A, METZGER JP AND VIELLIARD JM. 2005. The effect of structural and functional connectivity and patch size on the abundance of seven Atlantic Forest bird species. Biol Conserv 123: 507-519.

ULRICH W, ALMEIDA-NETO M AND GOTELLI NJ. 2009. A consumer's guide to nestedness analysis. Oikos 118: 3-17.

ULRICH W AND GOTELLI NJ. 2007. Disentangling community patterns of nestedness and species cooccurrence. Oikos 116: 2053-2061.

VEECH JA AND CRIST TO. 2007. Habitat and climate heterogeneity maintain beta-diversity of birds among landscapes within ecoregions. Global Ecol Biogeogr 16: 650-656.

VIELLIARD JME, ALMEIDA MEC, ANJOS L AND SILVA WR. 2010. Levantamento quantitativo por pontos de escuta e o Índice Pontual de Abundância (IPA). In: Matter SV et al. (Eds), Ornitologia e Conservação: Ciência Aplicada, Técnicas de Pesquisa e Levantamento, Rio de Janeiro: Technical Books, p. 47-60.

WATSON JEM, WHITTAKER RJ AND FREUDENBERGER D. 2005. Bird community responses to habitat fragmentation: how consistent are they across landscapes? J Biogeogr 32: 1353-1370.

WIENS JA. 1989. The ecology of bird communities, vol. 2: Processes and variations. Cambridge: Cambridge University Press, XVIII, p. 316.

WRIGHT DH, PATTERSON BD, MIKKELSON GM, CUTLER A AND ATMAR W. 1998. A comparative analysis of nested subset patterns of species composition. Oecologia 113: 1-20.

ZURITA GA AND BELLOCQ MI. 2010. Spatial patterns of bird community similarity: bird responses to landscape composition and configuration in the Atlantic forest. Landscape Ecol 25: 147-158. 